\title{
軽度低酸素環境曝露による脳血流自動調節の減弱 一周波数解析と大腿カフ解除法による検討一
}

\author{
曷川＼cjkstart元，小川洋二郎，青木＼cjkstart健，柳田＼cjkstart亮，岩崎 賢一 \\ 日本大学医学部社会医学系衛生学分野
}

\section{Acute Mild Hypoxia Impairs Dynamic Cerebral Autoregulation Assessed by Spectral Analysis and Thigh-Cuff Deflation}

\author{
Hajime KATSUKAWA, Yojiro OGAWA, Ken AOKI, Ryo YANAGIDA and Kenichi IWASAKI \\ Division of Hygiene, Department of Social Medicine, Nihon University School of Medicine
}

\begin{abstract}
Objectives: Acute hypoxia may impair dynamic cerebral autoregulation. However, previous studies have been controversial. The difference in methods of estimation of dynamic cerebral autoregulation is reported to be responsible for conflicting reports. We, therefore, conducted this study using two representative methods of estimation of dynamic cerebral autoregulation to test our hypothesis that dynamic cerebral autoregulation is impaired during acute exposure to mild hypoxia.

Methods: Eleven healthy men were exposed to $15 \%$ oxygen concentration for two hours. They were examined under normoxia $\left(21 \% \mathrm{O}_{2}\right)$ and hypoxia $\left(15 \% \mathrm{O}_{2}\right)$. The mean arterial pressure (MAP) in the radial artery was measured by tonometry, and cerebral blood flow velocity (CBFv) in the middle cerebral artery was measured by transcranial Doppler ultrasonography. Dynamic cerebral autoregulation was assessed by spectral and transfer function analyses of beat-by-beat changes in MAP and CBFv. Moreover, the dynamic rate of regulation and percentage restoration of $\mathrm{CBFv}$ were estimated when a temporal decrease in arterial pressure was induced by thigh-cuff deflation.

Results: Arterial oxygen saturation decreased significantly during hypoxia $(97 \pm 0 \%$ to $88 \pm 1 \%)$, whereas respiratory rate was unchanged, as was steady-state $\mathrm{CBFv}$. With $15 \% \mathrm{O}_{2}$, the very-low-frequency power of CBFv variability increased significantly. Transfer function coherence $(0.40 \pm 0.02$ to $0.53 \pm 0.05)$ and gain $(0.51 \pm 0.07 \mathrm{~cm} / \mathrm{s} / \mathrm{mmHg}$ to $0.79 \pm 0.11 \mathrm{~cm} / \mathrm{s} / \mathrm{mmHg})$ in the very-low-frequency range increased significantly. Moreover, the percentage restoration of CBF velocity determined by thigh-cuff deflation decreased significantly during hypoxia $(125 \pm 25 \%$ to $65 \pm 8 \%)$.

Conclusions: Taken together, these results obtained using two representative methods consistently indicate that mild hypoxia impairs dynamic cerebral autoregulation.
\end{abstract}

Key words: hypoxia（低酸素), spectral analysis（周波数解析）, dynamic cerebral autoregulation (動的脳血流自動調節), transfer function analysis (伝達関数解析), thigh-cuff deflation（大腿カフ解除法）

受付 2012 年 5 月 21 日, 受理 2012 年 8 月 7 日

Reprint requests to: Kenichi IWASAKI

Division of Hygiene, Department of Social Medicine, Nihon University School of Medicine, 30-1 Oyaguchi-Kamicho, Itabashi-ku, Tokyo 173-8610, Japan

TEL: +81(3)3972-8111 ext2265, FAX: +81(3)3974-9131

E-mail: iwasaki.kenichi@nihon-u.ac.jp

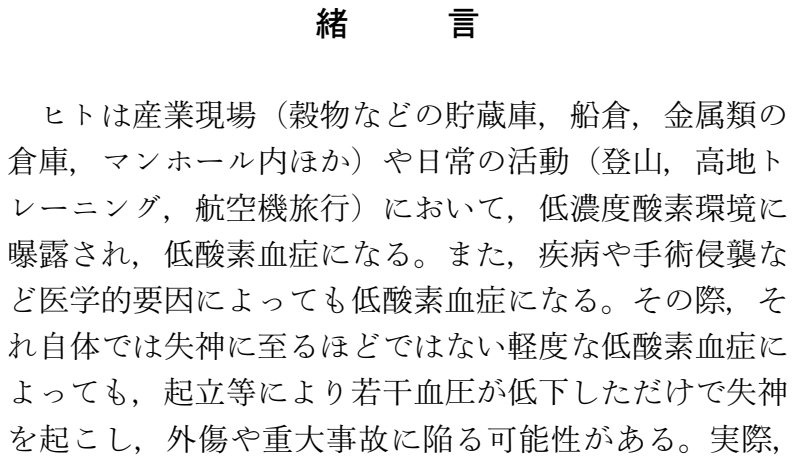


健常人への低酸素環境曝露の先行研究において, それ自 体では失神に至るほぞではない低酸素血症によっても起 立時失神の発症頻度が増すことが報告されている（1）。 失神に共通する病態生理は「脳全体の一過性低灌流」で あり（2），起立後の血圧低下が著しいため脳血流の供給 が不足する例が多いと考兄られている。しかしそれ以外 に，脳血流調節の異常が失神発症に関与している可能性 も示唆されている（3-5）。例えば, 起立により正常範囲 内で一過性の血圧低下が発生した際,「急激な血圧变化に 対する脳血流調節 (動的脳血流自動調節)」が悪化してい た場合には, 血圧低下に伴ら脳血流の減少の程度が増す, もしくは，血圧低下に伴い一度減少した脳血流が元のレ ベルにもどるまでに時間がかかり，失神を発症する可能 性が考えられる。つまり，それ自体では失神に至る流ど ではない軽度の低酸素血症であっても動的脳血流自動調 節を減弱させるのであれば，立位姿勢での脳血流の維持 機能が低下し, 失神や前失神症状のリスクを増加させる 可能性がある。もしこれが事実であれば,「産業現場での 酸欠に打ける事故」や，「旅客機内での急病人で最も多く を占めるとされる意識障害 (6)」，「登山や高地トレーニ ングでの事故」に強く関与する重要な病態生理といらこ とになる。さらに，手術後などの離床に際し，人工呼吸な どの肺への影響により低酸素血症が合併していれば，例 えそれが軽度であっても失神転倒のリスクを増加させる 可能性があり, 臨床上も重要な問題と考兄られる。か し, 低酸素血症が動的脳血流自動調節に与える影響につ いては，未だ研究者間で一致した見解が得られていない （7-10）。見解の相違を生む原因として, 動的脳血流自動 調節の評価に用いる手法の違いが指摘されている (11)。

動的脳血流自動調節の評価法として古典的に用いられ ているものに大腿カフ解除法がある (12)。この方法は, 「阻血後の大腿カフ解除により惹起された急速で一過性 の血圧低下に対する脳抵抗血管（細動脈）の拡張能力, 脳血流減少の程度, 及び，その回復率を評価できる」も のとして広く使われてきた。また近年は，周波数解析に より「脳血流変動量」と「脳血流変動の血圧変動への依 存度・伝達増幅率」を求める方法も用いられるようになっ た（13）。この周波数解析を用いた我々の先行研究におい ては，15\% 酸素濃度の低酸素環境への 5 分〜 5 時間の曝 露であっても，血圧の急激な変動に対してその影響を緩 衝できずに脳血流が大きな変動を示し不安定になるとい ら結果を得て, 低酸素は動的脳血流自動調節を悪化させ ると解釈した $(8,10)$ 。しかしながら, 最近, この周波数 解析の指標について，従来の解釈に反対の意見を呈する 報告もなされ (14), 我々の先行研究を再考する必要があ ると考えられた。

そこで，今回我々は，周波数解析と同時に，もら一つ の代表的な動的脳血流自動調節の評価方法である大腿力 フ解除法を用いて実験を行い,「両手法により評価した低 酸素環境下に打ける動的脳血流自動調節の変化が，とも に悪化と解釈できる」との仮説を検証した。

\section{方法}

本研究はへルシンキ宣言の方針に沿い，かつ，日本大 学医学部倫理委員会の承諾を得て行った。実験に際し, 被験者には事前に本研究の内容について実験説明書を用 いて説明し，文書にて同意を得た。

同意を得た健康成人男性 11 名 (平均土標準偏差: $23 \pm 3$ 歳， $172 \pm 4 \mathrm{~cm}, 70 \pm 11 \mathrm{~kg}$ ) を被験者に，低酸素テント 内で低酸素曝露を行った。低酸素テント入室前に通常大 気下で，被験者を仰臥位安静にし，脳血流速度の評価の ため側頭部に経頭蓋ドプラ血流計（WAKI; Atys Medical, Soucieu-en-Jarrest, France）のプローブを装着し中大脳動 脈の血流速度を連続測定した。また，tonometory 法によ る非観血的連続血圧計（JENTOW 7700; Colin，Aichi， Japan), II誘導の心電図 (BSM-4111; Nihon Kohden, Tokyo, Japan）を装着した。大腿カフ解除法用に両側大腿部にカ フを巻き内圧コントローラー（E20 Rapid cuff inflator: Hokanson, Bellevue, WA, USA）に接続した。呼吸状態の 把握のために, 経皮的動脈血酸素飽和度計, 呼気炭酸ガ スモニター（BSM-4111）を装着し, 動脈血酸素飽和度と 呼気終末二酸化炭素分圧を 1 分毎に記録した。多チャン ネル生体情報取得システム（Hem evolution; Notocord, Paris, France）を用いて，脳血流速度波形，血圧波形，心 電図波形をリアルタイムで一心拍毎のデータに変換し, 不整脈やノイズをモニターした。仰臥位安静で 15 分以 上経過した後に，周波数解析用に血圧波形と脳血流速 度波形を 6 分間記録した。その後，大腿カフ解除法に よる評価のため，大腿カフを 3 分間加圧（収縮期血圧 +30 mmHg，最高で $180 \mathrm{mmHg}$ ）して急速解除を行った。 大腿カフ解除による血圧，脳血流速度の一過性の低下か ら回復終了まで血圧波形と脳血流速度波形を記録した。

その後モニター電極他を外して低酸素テント内に移動 し，15\% 酸素環境に曝露した。曝露開始 1 時間 30 分後に 仰臥位となり，曝露前と同様な測定のためのモニターを 装着した。そして，低酸素曝露開始から 2 時間経過した 後, かつ仰臥位安静で 15 分以上経過した後に, 低酸素曝 露安静のまま血圧波形と脳血流速度波形を 6 分間記録し た。その後, 低酸素曝露前と同様に大腿カフ解除法を実 施した。

\section{解析評価}

\section{周波数解析（spectral analysis）}

まず，一心拍毎の平均血圧と平均脳血流速度について 各々の自発変動に高速フーリエ変換 (FFT: fast Fourier transform）を施しスペクトルを得た。次に，平均血圧の自 発変動に対する平均脳血流速度変動の関係を伝達関数解 析（Transfer Function Analysis）にて解析した（図 1)。こ の場合, Transfer Function Gain (伝達増幅率) と Coherence （関連性，依存度）の解釈としては，值が高いほど血圧の 変動に対し脳血流変動の依存度が高く, 脳血流が大きく 


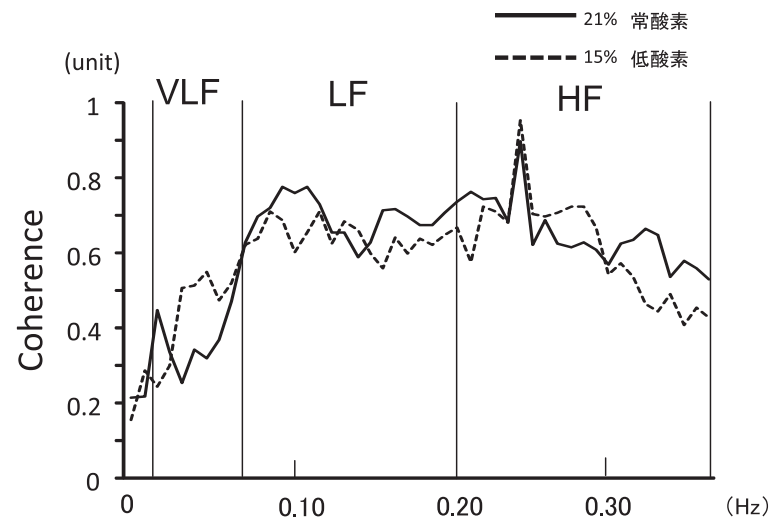

$(\mathrm{cm} / \mathrm{s} / \mathrm{mmHg})$

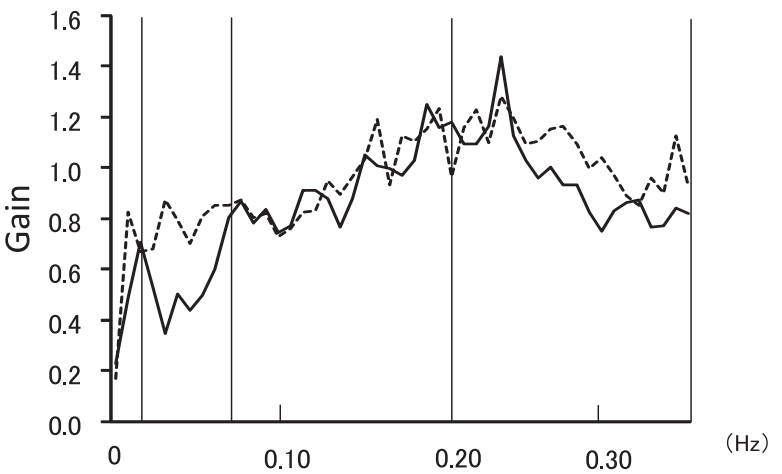

図 1 平均血圧変動と平均脳血流速度変動の伝達関数解析の結 果 (群平均)。一心拍毎の平均血圧変動と平均脳血流速度変動の 関係を伝達関数解析（Transfer Function Analysis）にて解析した。 上段 : 平均血圧変動と平均脳血流速度変動の Coherence（関連 性, 依存度)。下段: 血圧変動から脳血流速度変動への Gain（伝 達増幅率）。VLF, very low frequency range（超低周波数帯：0.02 $\sim 0.07 \mathrm{~Hz}$ ) ; LF, low frequency range（低周波数帯 : $0.07 \sim 0.20$ $\mathrm{Hz}$ ) ; HF, high frequency range（高周波数帯 : $0.20 \sim 0.35 \mathrm{~Hz}$ )。

変動する事を意味することから自動調節機能の悪化と評 価している $(8,10)$ 。その際, 先行研究を参考にし (13), 血圧変動の速さに対応する動的脳血流自動調節の特性の 違いから, 周波数帯を, 超低周波数帯 $0.02 \sim 0.07 \mathrm{~Hz}$, 低 周波数帯 $0.07 \sim 0.2 \mathrm{~Hz}$, 高周波数帯 $0.2 \sim 0.35 \mathrm{~Hz}$ と定義 した。これ等の解析はPC上で市販ソフト（DADiSP; DSP Development, Cambridge, MA, USA）にて行った。

大腿カフ解除法（thigh cuff deflation）

大腿カフを収縮期血圧より $30 \mathrm{mmHg}$ 高く加圧し（最高 $180 \mathrm{mmHg}$ ），3 分後に急速解除することで一過性の血圧 低下を生じさせた。カフ解除前 4 秒の值を基準值とし, 解除直後 $1 \sim 3.5$ 秒の脳抵抗血管の拡張能 (dROR: the rate of dynamic cerebral autoregulation） と脳血流速度の最低值 （通常解除後 6 秒以内）を算出した。さらに, 減少した脳 血流は, 正常時はカフ解除後 10 秒以内に基準值に回復す るため (12), 6〜10秒に打ける回復率も算出した(図 2$)$ 。

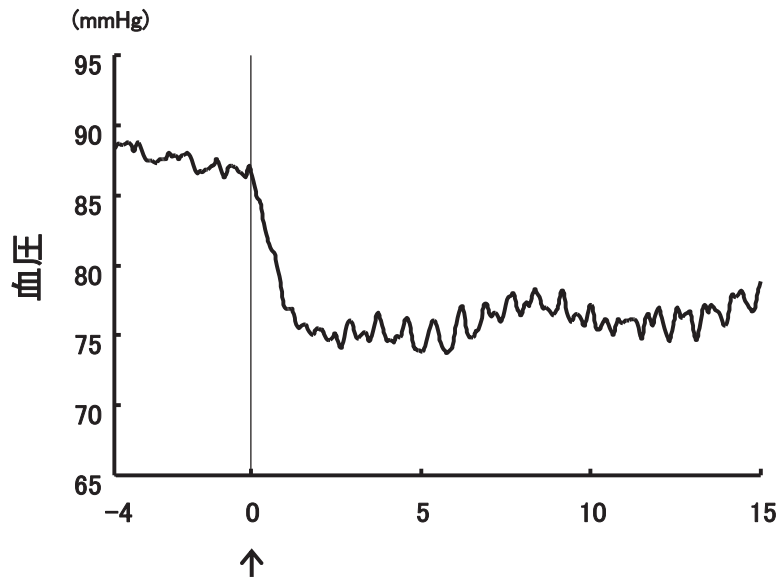

大腿力フ解除

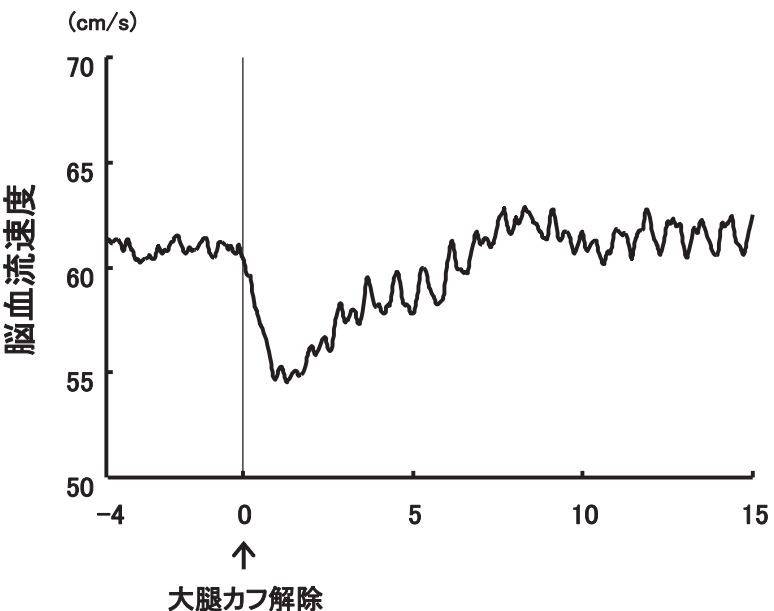

図 2 大腿カフ解除法の代表例の血圧, 脳血流の反応。大腿力 フを収縮期血圧より $30 \mathrm{mmHg}$ 高く加圧し（最高 $180 \mathrm{mmHg}$ )，3 分後に急速解除した後の, 一過性の血圧低下とそ扎に伴う, 脳 血流速度の低下と回復が認められる。力フ解除前 4 秒の值を基 準值とし, 解除直後 $1 \sim 3.5$ 秒の脳血管抵抗の低下率, 脳血流速 度の最低值（通常解除後 6 秒以内）, 6 10 秒に打村る回復率を 算出した。

統計

統計解析には，対応のある $\mathrm{t}$ - 検定を用い， $\mathrm{P}<0.05$ を もって有意とした。

\section{結果}

経皮的動脈血酸素飽和度は，低酸素曝露下で有意に低 下し軽度低酸素血症になった $(21 \%$ 常酸素下 $97 \pm 0 \%$, 低 酸素曝露下 $88 \pm 1 \%$ )。また，呼気終末二酸化炭素濃度も 有意に低下した（表 1）。しかしながら，平均脳血流速度 を含め，その他の呼吸数，平均血圧，心拍数は有意な変 化を示さなかった（表 1）。

平均血圧の自発変動は何れの周波数帯でも有意な変化 を示さなかった（表2）。しかしながら，平均脳血流速度 の変動は, ゆっくりとした変動部分である超低周波数帯 （0.02 $0.07 \mathrm{~Hz}: 50$ 秒〜 14 秒 $/ 1$ 周期）でのみ，低酸素 
表 1 区間平均による指標の比較

\begin{tabular}{lcc}
\hline & $21 \%$ 常酸素 & $15 \%$ 低酸素 \\
\hline 経皮的動脈血酸素飽和度 $(\%)$ & $97 \pm 0$ & $88 \pm 1^{*}$ \\
呼吸数 (回 / 分) & $14 \pm 1$ & $15 \pm 1$ \\
呼気終末二酸化炭素濃度 $(\mathrm{mmHg})$ & $40 \pm 1$ & $37 \pm 0^{*}$ \\
平均血圧 $(\mathrm{mmHg})$ & $81 \pm 2$ & $77 \pm 2$ \\
脳血流速度 $(\mathrm{cm} / \mathrm{s})$ & $63 \pm 3$ & $66 \pm 3$ \\
心拍数 (回 / 分) & $59 \pm 2$ & $63 \pm 2$ \\
\hline
\end{tabular}

数值はグループ平均土標準誤差 $(*: p<0.05$ vs. $21 \%$ 常酸素)

\section{表 2 周波数解析による指標の比較}

\begin{tabular}{|c|c|c|}
\hline & $21 \%$ 常酸素 & $15 \%$ 低酸素 \\
\hline $\operatorname{VLF}_{\mathrm{MBP}}\left(\mathrm{mmHg}^{2}\right)$ & $5.04 \pm 1.26$ & $7.70 \pm 1.87$ \\
\hline VLFvel $\left(\mathrm{cm}^{2} / \mathrm{s}^{2}\right)$ & $2.87 \pm 0.68$ & $7.60 \pm 1.90^{*}$ \\
\hline CoherenceVLF（Units） & $0.40 \pm 0.02$ & $0.53 \pm 0.05^{*}$ \\
\hline GainVLF $(\mathrm{cm} / \mathrm{s}$ per $\mathrm{mmHg})$ & $0.51 \pm 0.07$ & $0.79 \pm 0.11 *$ \\
\hline $\mathrm{LF}_{\mathrm{MBP}}\left(\mathrm{mmHg}^{2}\right)$ & $2.84 \pm 0.57$ & $2.64 \pm 0.43$ \\
\hline LFvel $\left(\mathrm{cm}^{2} / \mathrm{s}^{2}\right)$ & $1.86 \pm 0.29$ & $2.30 \pm 0.34$ \\
\hline CoherenceLF (Units) & $0.70 \pm 0.04$ & $0.64 \pm 0.05$ \\
\hline GainLF $(\mathrm{cm} / \mathrm{s}$ per $\mathrm{mmHg})$ & $0.89 \pm 0.06$ & $0.91 \pm 0.07$ \\
\hline $\mathrm{HF}_{\mathrm{MBP}}\left(\mathrm{mmHg}^{2}\right)$ & $0.21 \pm 0.04$ & $0.20 \pm 0.03$ \\
\hline HFvel $\left(\mathrm{cm}^{2} / \mathrm{s}^{2}\right)$ & $0.24 \pm 0.03$ & $0.33 \pm 0.04$ \\
\hline CoherenceHF (Units) & $0.65 \pm 0.05$ & $0.61 \pm 0.05$ \\
\hline GainHF（cm/s per mmHg） & $0.95 \pm 0.09$ & $1.04 \pm 0.08$ \\
\hline
\end{tabular}

数值はグループ平均土標準誤差 $(*: p<0.05$ vs. $21 \%$ 常酸素 $)$ $\mathrm{HF}$, 高周波数帯 (high frequency) ; LF, 低周波数帯（low frequency); MBP, 平均血压変動 (mean blood pressure variability); vel, 脳血流速度変動 (cerebral blood flow velocity variability); VLF，超低周波数帯 (very low frequency).

\section{表 3 大腿カフ圧迫法における脳血流の回復}

\begin{tabular}{lcc}
\hline & $21 \%$ 常酸素 & $15 \%$ 低酸素 \\
\hline $\mathrm{dROR}(\% / \mathrm{s})$ & $25 \pm 4$ & $20 \pm 5$ \\
脳血流速度最低值 $(\mathrm{cm} / \mathrm{s})$ & $53 \pm 3$ & $54 \pm 2$ \\
脳血流回復率 $(\%)$ & $125 \pm 25$ & $65 \pm 8^{*}$
\end{tabular}

数值はグループ平均士標準誤差（* $: \mathrm{p}<0.05$ vs. $21 \%$ 常酸素） dROR, 脳抵抗血管拡張能 (dynamic rate of autoregulation); 脳 血流回復率, 大腿力フ解除後 $6 \sim 10$ 秒に打ける脸血流回復率.

環境下において有意に増加した（表2）。脳血流自動調節 機能の評価指標の Transfer Function Gain と Coherence b 超低周波数帯においてのみ, 低酸素環境下で有意に増加 し, この周波数帯での調節機能悪化が示唆された（表 2)。 また，大腿カフ解除法では，「解除後 $6 \sim 10$ 秒におけ る回復率」が低酸素曝露下で有意に低下した（表 3 )。し かし，その他の解析指標の dROR（脸抵抗血管の拡張能） や脳血流速度の最低值は変化しなかった（表 3)。

\section{考察}

\section{脳血流自動調節}

脳血流自動調節とは，様々な要因による血圧変化に対 応して, 脳細動脈を収縮または拡張させて脳血管抵抗を
調節し，脳血流の変化を抑える作用のことである。調節機 序としては，「筋原性調節」，「電解質やホルモンなどが介 在する代謝性調節」，「血管内皮由来因子性調節」，「自律 神経性調節」などがあるとされる（15）。脳血流調節には, 「静的」脳血流自動調節と「動的」脳血流自動調節の二つ の考方方がある。「静的」脳血流自動調節とは，一定時間 内の平均值としての血圧 (以下, 静的血圧) と脳血流（以 下，静的脳血流）の関係に着目した考え方で，この自動 調節が正常に働いていれば，静的血圧がある範囲内（平 均血圧 $60 \sim 150 \mathrm{mmHg}$ ）で变化しても静的脳血流は， ほ ぼ一定に保たれると考えられている。一方，「動的」脳血 流自動調節とは，より短い時間で起こる速い血圧変化と 脳血流変化に着目した考方である。急速な変化に注目 すると, 血圧変化に伴って脳血流も影響を受け変化して いることが解明されてきた $(12,13)$ 。つまり，急激な変 化や変動を考慮して評価を行うと，古典的な脳血流自動 調節 (「静的」脳血流自動調節) は成り立っていないこと がわかり，「動的」脳血流自動調節の概念が導入された。

\section{動的脳血流自動調節の評価法}

動的脳血流自動調節の主な評価法として, 今回用いた, 周波数解析と大腿力フ解除法がある $(12,13)$ 。周波数解 析は，まずある範囲の周波数域ごとに脳血流の「変動量」 を数值化する。そして, 血圧変動を入力, 脳血流変動を 出力として，両者の関係を数值化して評価する方法であ る。その際, ある周波数帯の脳血流の「変動量」が増加 していれば，脳血流が「平均值」を中心に上下により大 きく変動し不安定と考える。さらに, 血圧変動と脳血流 変動の関係の「Coherence（相関性, 依存度）」が大きい ほど脳血流変動は血圧変動に伴って変化していると考 え,「Gain (伝達増幅率)」が大きい注ど血圧変動がより 大きく脳血流変動へ伝わっている（伝達を緩衝する能力 が小さい）と考光，動的脳血流自動調節が悪化したと解 釈する。つまり，動的脳血流自動調節が悪化した状況で は，血圧が急激に変化した際に，その血圧変化の影響を 緩衝できず, 脳血流は血圧変動に依存して大きく変動し, 脳血流が不安定であるとの概念である。

我々の先行研究においては $(8,10)$, この周波数解析を 用い, $15 \%$ 酸素濃度の低酸素環境に曝露した際の動的脳 血流自動調節を評価した。これらの研究 $(8,10)$ では, 曝 露時間と体位の違いにより, 基となる血圧変動量やその 変化などが今回の結果と異なるものの, 低酸素環境曝露 で Coherence もしくは Gain が増加したことから，急激な 血圧変動の影響を緩衝する能力が低下し, 動的脳血流自 動調節が悪化したと結論した。しかしながら，最近，こ の周波数解析の指標について, 従来の解釈方法に反対の 意見を呈する報告が Romero らからなされた（14）。彼ら は，脱水状態での起立負荷中に脳血流変動と血圧变動間 のCoherence が増加し脳血流変動量が増加することを明 らかにしたが，この結果を，脱水時の起立により脳への 血流供給が減少したことへの代償反応と考え, 動的脳血 
流自動調節機能が良好になったと解釈している。この解 釈方法からすると, 我々の先行研究 $(8,10)$ の結果も低酸 素により動的脳血流自動調節が良好になったと捉えるこ とができる。そこで今回, 動的脳血流自動調節の評価に 周波数解析だけでなく大腿カフ解除法も同時に用いて研 究を行い, 両手法の結果から軽度低酸素で起こっている 変化を解釈すべきと考えた。

\section{当実験結果の解釈}

今回の結果では，低酸素曝露後に明らかに低酸素血症 になっていたにもかかわらず，静的脳血流速度は変化し ていなかった。脳への酸素供給量は動脈血液の酸素含量 と脳血流量の積であることから，本研究では，静的な脳 への酸素供給量は通常より減少していたことを意味す る。つまり, この程度の軽度低酸素血症では, 動脈血の 酸素含量の低下に対する脳抵抗血管の拡張反応 (15) は 十分には起こらず，静的な脳への酸素供給低下は代償さ れないと考えられた。

次に動的脳血流自動調節に関する本研究の周波数解析 の結果としては, 低酸素曝露により, 超低周波数帯 $(0.02$ $\sim 0.07 \mathrm{~Hz}, \quad 14 \sim 50$ 秒 $/ 1$ 周期 $)$ においてのみ Coherence, Gain が増加した。つまり,「脳血流変動の血圧への依存 度と, 血圧変動から脳血流変動への伝達増幅率が増加し, それに伴ってこの周波数帯に抢ける脳血流変動が増加」 したことを示していた。我々の先行研究においては (8), $15 \%$ 酸素濃度の低酸素に 1 時間に満たない短時間曝露し た場合は, 今回の結果とは異なり, 血圧変動自体が増加 していたが，超低周波数帯の Coherence, Gain は今回同様 に増加していた。一方, 5 時間曝露を行った先行研究 (10) では，座位であったため曝露前の超低周波数帯の Coherence が高く, 今回の結果と異なり曝露 2 時間では有意な 差が認められていないが，超低周波数帯の Gain は曝露 2 時間で有意に増加していた。2つの先行研究にくらべ, 今 回の結果は，基となる血圧変動が変わらないにも拘らず 超低周波数帯での久 Coherence, Gain が共に増加してお り,「超低周波数帯に打ける血圧変動の影響を緩衝する脳 循環の能力が減弱した」ことを，より明確に示唆したと 思われた。

ただし，本研究の超低周波数帯で認められた変化を， 従来通り「動的脳血流自動調節の悪化」として捉えて良 いかは，前述のごとく当解析指標の解釈に関し異なる意 見も呈されたため (14), 大腿カフ解除法の結果と合わせ て解釈することが重要と思われる。今回, 大腿力フ解除 により惹起された一過性の血圧低下に対する脳血流変化 に扣いては, 初期の脳血流減少量（脸血流速度最低值） は低酸素環境でも変化を示さなかった。一方，解除後 6 〜 10 秒に扣ける回復率が, 低酸素曝露時に有意に低下し ていた。つまり，大腿カフ解除法による一過性の急速な 血圧低下に対し，解除直後の脳血流減少を緩衝する自動 調節システムは低酸素により影響を受けないものの，脳 血流減少後の緩徐な回復に関連した自動調節システムは
低酸素の影響を受けて，その機能が減弱したことが考え られた。つまり，「周波数解析」打よび「大腿カフ解除 法」の両結果を合わせて考察すれば，緩徐な血圧変動に 対応した脳血流自動調節システムのみが低酸素により影 響を受け緩衝能力が減弱し，脳血流の緩徐な変動が大き くなり，一過性の血圧低下に対しては，血圧低下に伴い 一度減少した脳血流が元のレベルにもどるまでに時間が かかると解釈することが妥当と思われた。

今回の結果より，動的脳血流自動調節は対応する変動 の速度ごとに調節システムが異なり，低酸素により影響 をらける調節システムと影響を受けない調節システムが あると思われた。動的脳血流自動調節の特に超低周波数 帯領域には自律神経の関与があることが自律神経節遮断 薬を用いた研究から示唆されている(16)。また，低酸素 は自律神経バランスを変化させることが解っている (17)。これらのことから，低酸素が動的脳血流自動調節 を減弱させるメカニズムの一つとして，低酸素により自 律神経活動が変化し二次性に自動調節が減弱したことが 考光らる。

\section{実験の限界}

経頭蓋ドプラ血流計によって測定しているのは中大脳 動脈血流「速度」であって，脳血流「量」ではない。そ のため, 血流速度変化を血流量変化の代わりに用いるこ とが可能なのは, 「測定する血管の直径変化が極めて小さ い」といら仮定が成り立っている場合だけであるので注 意を要する。しかし, ${ }^{133} \mathrm{Xe}$ クリアランス測定 (18), Singlephoton emission computed tomography (SPECT) (19), 内頝 動脈の電磁流量計 $(20,21)$ を用いた研究では, 経頭蓋ド プラ血流計で計測される中大脳動脈血流速度変化と, 脳 全体への血流量変化の間には高い相関が示されている。 また，脳血管造影時の脳血管径の変化を測定した研究に おいても(22), 内頝動脈や中大脳動脈本幹などの比較的 大きな脳血管の径は，スパスムなどを起こさない限り， 造影剤などの高浸透圧液の投与や血中二酸化炭素濃度の 変化によってもほとんど変化を生じないことが示されて いる。さらに，極度の低酸素曝露は例外として中等度の 低酸素までは，中大脳動脈の基部の血管径は変化しない

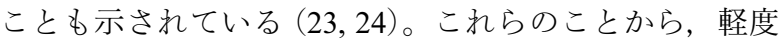
低酸素曝露時は，中大脳動脈血流「速度」の変化は，脳 血流「量」変化をかなり高い精度で表していると考えら れる。ただし，将来的には，軽度低酸素実験に拈いて血 流速度と同時に中大脳動脈血管径を評価する実験を行う ことが望ましいと思われる（24）。

\section{ま と め}

諸言で述べたごとく，低酸素における脳血流調節の生 理学的変化を明らかにすることは，産業衛生や，航空医 学，スポーッ医学，臨床医学において重要である。今回， 「両手法により評価した低酸素環境下に打ける動的脳血 
流自動調節の変化が，ともに悪化と解釈できる」との仮 説をたて，その検証を行った。低酸素環境曝露 2 時間後 には, 周波数解析の緩徐な変動に対応した緩衝能力の指 標が減弱し, 大腿力八解除法による解除後 $6 \sim 10$ 秒にお ける回復率が有意に低下したことから，低酸素血症は， 動的脳血流自動調節機能を減弱させると考兄られた。つ まり，低酸素血症では，通常より脳への酸素供給量が低 下しているら光, 動的脳血流自動調節機能が減弱するた め, 一過性の血圧低下が発生した際には，血圧低下に伴 い一度減少した脳血流が元のレベルにもどるまでに時間 がかかり, 失神を呈する可能性が高くなると考兄られた。

本論文の要旨は, 第 82 回日本衛生学会にて発表を行っ た。本研究は日本学術振興会の科研費 (21590667) の助 成を受けたものである。

\section{文献}

( 1 ) Blaber AP, Hartley T, Pretorius PJ. Effect of acute exposure to $3660 \mathrm{~m}$ altitude on orthostatic responses and tolerance. J Appl Physiol 2003;95:591-601.

(2) Soteriades ES, Evans JC, Larson MG, Chen MH, Chen L, Benjamin EJ, Levy D. Incidence and prognosis of syncope. N Engl J Med 2002;347:878-885.

( 3 ) Grubb BP, Gerard G, Roush K, Temesy-Armos P, Montford P, Elliott L, Hahn H, Brewster P . Cerebral vasoconstriction during head-upright tilt-induced vasovagal syncope. A paradoxic and unexpected response. Circulation 1991;84: 1157-1164.

( 4 ) Obara C, Kobayashi Y, Ueda H, Nakagawa H, Kikushiama S, Baba T, Ozawa M, Katagiri T. Hypersensitivity of cerebral artery response to catecholamine in patients with neurally mediated syncope induced by isoproterenol. Am J Cardiol 2000;85:1376-1379.

( 5 ) Ocon AJ, Medow MS, Taneja I, Clarke D, Stewart JM. Decreased upright cerebral blood flow and cerebral autoregulation in normocapnic postural tachycardia syndrome. Am J Physiol Heart Circ Physiol 2009;297:H664-H673.

（6）林 弘子, 沼田美和子, 大川康彦, 土方康義, 門倉真 人，牧 信子，松永直樹，大越裕文，野口淑子，宮崎 寛, 飛鳥田一朗, 加地正伸. 航空機内に打㴔病人 発生状況とその救急医療に関する検討. 宇宙航空環境 医学 2007;44:119.

( 7 ) Van Osta A, Moraine JJ, Melot C, Mairbaurl H, Maggiorini M, Naeije R. Effects of high altitude exposure on cerebral hemodynamics in normal subjects. Stroke 2005;36:557-560.

( 8 ) Iwasaki K, Ogawa Y, Shibata S, Aoki K. Acute exposure to normobaric mild hypoxia alters dynamic relationships between blood pressure and cerebral blood flow at very low frequency. J Cereb Blood Flow Metab 2007;27:776-784.

(9) Ainslie PN, Ogoh S, Burgess K, Celi L, McGrattan K, Peebles K, Murrell C, Subedi P, Burgess KR. Differential effects of acute hypoxia and high altitude on cerebral blood flow velocity and dynamic cerebral autoregulation: alter- ations with hyperoxia. J Appl Physiol 2008;104:490-498.

(10) Nishimura N, Iwasaki K, Ogawa Y, Aoki K. Decreased steady-state cerebral blood flow velocity and altered dynamic cerebral autoregulation during 5-h sustained 15\% O2 hypoxia. J Appl Physiol 2010;108:1154-1161.

(11) Subudhi AW, Panerai RB, Roach RC. Acute hypoxia impairs dynamic cerebral autoregulation: results from two independent techniques. J Appl Physiol 2009;107:1165-1171.

(12) Aaslid R, Lindegaard KF, Sorteberg W, Nornes H. Cerebral autoregulation dynamics in humans. Stroke 1989;20:45-52.

(13) Zhang R, Zuckerman JH, Giller CA, Levine BD. Transfer function analysis of dynamic cerebral autoregulation in humans. Am J Physiol Heart Circ Physiol 1998;274:H233$\mathrm{H} 241$.

(14) Romero SA, Moralez G, Rickards CA, Ryan KL, Convertino VA, Fogt DL, Cooke WH. Control of cerebral blood velocity with furosemide-induced hypovolemia and upright tilt. J Appl Physiol 2011;110:492-498.

(15) Paulson OB, Strandgaard S, Edvinsson L. Cerebral autoregulation. Cerebrovasc Brain Metab Rev 1990;2:161-192.

(16) Zhang R, Zuckerman JH, Iwasaki K, Wilson TE, Crandall $\mathrm{CG}$, Levine BD. Autonomic neural control of dynamic cerebral autoregulation in humans. Circulation 2002;106:18141820 .

(17) Iwasaki K, Ogawa Y, Aoki K, Saitoh T, Otsubo A, Shibata S. Cardiovascular regulation response to hypoxia during stepwise decreases from $21 \%$ to $15 \%$ inhaled oxygen. Aviat Space Environ Med 2006;77:1015-1019.

(18) Bishop CC, Powell S, Rutt D, Browse NL. Transcranial Doppler measurement of middle cerebral artery blood flow velocity: a validation study. Stroke 1986;17:913-915.

(19) Larsen FS, Olsen KS, Hansen BA, Paulson OB, Knudsen GM. Transcranial Doppler is valid for determination of the lower limit of cerebral blood flow autoregulation. Stroke 1994;25:1985-1988.

(20) Lindegaard KF, Lundar T, Wiberg J, Sjøberg D, Aaslid R, Nornes H. Variations in middle cerebral artery blood flow investigated with noninvasive transcranial blood velocity measurements. Stroke 1987;18:1025-1030.

(21) Newell DW, Aaslid R, Lam A, Mayberg TS, Winn HR. Comparison of flow and velocity during dynamic autoregulation testing in humans. Stroke 1994;25:793-797.

(22) Huber P, Handa J. Effect of contrast material, hypercapnia, hyperventilation, hypertonic glucose and papaverine on the diameter of the cerebral arteries. Angiographic determination in man. Invest Radiol 1967;2:17-32.

(23) Poulin MJ, Robbins PA. Indexes of flow and cross-sectional area of the middle cerebral artery using doppler ultrasound during hypoxia and hypercapnia in humans. Stroke 1996; 27:2244-2250.

(24) Wilson MH, Edsell ME, Davagnanam I, Hirani SP, Martin DS, Levett DZ, Thornton JS, Golay X, Strycharczuk L, Newman SP, Montgomery HE, Grocott MP, Imray CH; Caudwell Xtreme Everest Research Group. Cerebral artery dilatation maintains cerebral oxygenation at extreme altitude and in acute hypoxia - an ultrasound and MRI study. J Cereb Blood Flow Metab 2011;31:2019-2029. 